\title{
Music and Spirituality-Introduction
}

\author{
Edward Foley \\ Catholic Theological Union, 5416 S. Cornell Ave., Chicago, IL 60615, USA; E-Mail: foley@ctu.edu
}

Received: 13 May 2015 / Accepted: 15 May 2015 / Published: 19 May 2015

Across time and geography people have known the power of music for evoking the gods and acquiring spiritual insight. Whether arising as a textless chant by a single voice or a percussive auditory event for ritual dance, music in its various modes is a virtually ubiquitous companion to religious and spiritual practices. Not only a constant accompaniment to one's spiritual trek, musical compositions from the great oratorios of Handel to the soundtrack to the movie trilogy Lord of the Rings also serve as powerful metaphors and inspirations for that journey.

In previous research I have suggested that one of the reasons for the power of music in the spiritual realm is related to the very nature of sound [1,2], of which music is one of its most refined genres. This is based upon the presupposition that different senses provide different epistemic experiences. As a distinctive avenue to knowing, hearing enables the human imagination and thus the religious imagination to grasp and experience the transcendent in a unique and spiritually prized manner.

For example, sound experiences are by their very nature transitory. While a sculpture can sit in a museum or even outdoors for centuries without requiring anything to sustain its beauty, sound only exists if it is being produced in the present - either by live or reproduced sound production. A record, cassette, CD or even musical score is not "music" the way Michelangelo's (d. 1564) David is a sculpture. The great Tuscan artist carved David and then let it stand for over three centuries outside in Florence's public square without any substantive care. Maria Callas' (d. 1977) performance of "D'amor sull'ali rosee" from Il Trovatore, however, can only be experienced if you were present for a performance of it, or if someone plays a recording of the same in the here and now. Sound is an immersion in temporality.

Because of that, sound has an inherent dynamism about it. While using hammer and chisel on a piece of marble is certainly dynamic, once the piece is sculpted the dynamism emanating from the piece is all but muted, and the fundamental dynamic responsibility lies with the observers of the piece in the process of reception. Sound on the other hand embodies movement. While there are "light waves" they are much too fast for human's to perceive their movement. Sound waves, on the other hand, move at approximately 1,120 feet per second at 15 degrees Celsius: slow enough to be perceived by human beings as moving. 
Sound is also an experience of the intangible. Sculptors employ marble, painters oils or acrylics or water colors on canvas or wood or paper. No matter what the instrument-whether a double reed or the human voice or a magnificent pipe organ - the real stuff of sound is controlled air. Whether that air is hammered into a melody by a Steinway grand or blasted into existence by a shofar, no one "sees" the air or ordinarily "smells" it or "feels" it. If you happen to be standing in front of a Heldentenor with bad breath you might get a whiff or feel the blast, but these do not go to the essence of sound production or music making. Sound and its refined sibling music are an exercise in the insubstantial and elusive.

I have further explored how sound could be considered a powerful form of engagement. Plato (d. 347 BCE) understood this, which is why he is sometimes considered the apostle of the visual. Plato did not trust sound, especially the sound of the epic poets, because he perceived that the listener could not separate her or himself from the sound event [3]. It is sound, the voice, the music, the beat, that prompts people to move: music videos without sound would entice few to dance.

Finally, sound is often perceived as an indicator of presence. When we heard a sound in the dark, a squeaky door, an unexplained rattle, the wind rustling through the leaves the human imagination not only wonders "what's there" but more often "who's there." The acoustic disturbance is not only perceived as a gauge of animation and of "life" but also of human presence.

These attributes of sound can suggest some of the reasons why that refined manipulation of sound we call music is so often employed as a medium of transcendence and a language of spirituality. It's elusive but dynamic impermanence evokes images of a divine spirit that sweeps in and through our lives, present but not containable. Its intangibility even in the human realm bodes well for its capacity to penetrate into the realm of gods and traverse the spirit world in its return trip bearing messages of solace or inspiration. Finally, its aptitude for invitation and genius for conjuring the potential for presence, renders sound and its cherished sibling music as acoustics symbols unparalleled in their talent for orientating the human spirit toward others and even the transcendent Other.

A final reflection on sound, spirituality and the human anatomy: it was the great Roman Catholic German theologian Karl Rahner (d. 1984) who posited - with the help of transcendental philosophythat human beings were naturally inclined to be "hearers" of the Word ([4], 24ff). While that could be considered a religiously limited framework, particularly cued to the Abrahamic traditions with their emphasis on the divine Word mediated through humanly received and proclaimed texts, it also suggests something more universal. No matter what our religious or spiritual orientation, human beings are virtually always born with eye-lids, but no "ear-lids." That is, we are born metaphorically open to sound, often identified as the first sense to develop [5] and the last to fade [6]. Employing metaphors from the Roman philosopher Boethius (d. $524 \mathrm{CE}$ ), we are not only born open to engage music of the body and instrumental but also the music of the "spheres" (musica mundana) [7] or, in my language, the music of transcendence and spirituality.

The spheres in which one can perceive a spiritual acoustic are manifold. My respected colleagues in this volume evoke some of that richness without in any way mapping or depleting the sonic galaxy. For example, sketching something of the broadness of this cosmic landscape, Peter Bannister engages the writings of Theodor Adorno and the compositions of Olivier Messian. In this juxtaposition of challenging viewpoints and practices he demonstrates that religious composers can ance engage the radicality of modernistic perspectives and yet write powerful and expressive religious music. In a yet 
philosophical but even more explicitly theological vein, Maeve Louis Heaney employs Arvo Pärt's musical composition Spiegel im Spiegel as a case study for exploring to what extent a single piece of music has the capacity to mirror or transmit religious experience and even reveal God's presence. Also in a theological mode, Chiara Bertoglio explores both ancient and contemporary musical practices among Christians to explicate how they reflect, refract and reveal anew understandings of the central Christian doctrine of the Trinity.

Providing a particularly Eastern-Christian perspective, Ivan Moody draws our attention to the music of the Orthodox churches. Specifically he ponders the theological character of the liturgical music of the Orthodox churches in dialogue with ancient Christian writings of the "Church Fathers" to demonstrate how Orthodox understandings of theology are transmitted through the liturgical arts. Exercising his scholarship across decades and denominations Paul Westermeyer explicates how God's Word, from a Christian perspective, breaks through in music, regardless of the intention of the composer: a symbol of how the divine Word seeks out individuals even though they are not on a God-quest.

Innocent Smith also probes larger questions through a specific practice of the Roman Catholic Dominican religious order beginning in the $13^{\text {th }}$ century. His focus is on the emergence and development of a form of western plainchant peculiar to the Dominican Order, with an eye toward how such chant contributed to the growth and preservation of the identity of the community of men and women who brought it to life. The Dominican theme continues with Michael O'Connor. Turning from sung plainchant, this author examines to what extent solo instrumental music - here the organ-was judged capable of conveying a specific religious meaning or communicating an appropriate textual message in an age of growing secularity.

Theologizing and re-theologizing out of his own Presbyterian tradition, William Harrison Taylor employs musical sources as a way to challenge a larger question: whether the dichotomy between theology and spirituality is sustainable, and how music might offer a bridge framework for healing this unnecessary and untenable breach. Turning to the practices of African American Baptists, Therese Smith shares the fruit of her field work at one Baptist congregation in Mississippi. In particular, she demonstrates how the essential presence of music throughout the religious service calls forth and sustains the perceived presence of the Holy Spirit in such an event.

In a decidedly more secular vein, Mark Duffett considers Elvis Presley as a performer of gospel music. He discerns how his performance of sacred music and his fans' reaction to that music is not easily categorized as sanctification or idolatry, but is a much more complex phenomenon, that may be better illuminated through Émile Durkheim's theory of religion.

In a final turn to the more empirical, Peter Atkins and Emery Schubert bring the social sciences to bear in examining to what extent "spiritual experiences" are intrinsic or extrinsic to the music itself. Their conclusions that the spiritual "comes to life" in music is both a helpful insight and also a clarion call for more empirical work on the relationship between music and spiritual experiences.

This wondrous array of studies and reflections does not, of course, exhaust any discussion of the relationship between music and spirituality. On the other hand, it does provide a series of credible and notable "dots" that allow and invite you, the reader, to connect them each in your own way and, in the process, acquire new insights and appreciation for the musical-spiritual dynamic. 


\section{References and Notes}

1. Edward Foley. "Music as Sound Spirituality." The Way Supplement 96 (1999): 56-64. I am grateful to the editors of that volume for allowing me to rehearse here, in sometimes fresh ways, many ideas explicated in that article.

2. Edward Foley. “Toward a Sound Theology.” Studia Liturgica 23, no. 2 (1993): 121-39.

3. Eric Havelock. Preface to Plato. Cambridge and London: Balknap Press, 1963.

4. Karl Rahner. Foundations of Christian Faith: An Introduction to the Idea of Christianity. Translated by William Dych. New York: Seabury Press, 1978.

5. Andrea Bader-Rusch. "In the Beginning was the Word: Language and the Womb." In The Multilingual Mind: Issues Discussed by, for, and about People Living with Many Languages. Edited by Trace Tokuhama-Espinosa. Westport CT: Praeger Publishers, 2003, 101-08.

6. Kathy Graham. "Let's Talk about Death." $A B C$ Science, 18 May 2006. http://www.abc.net.au/science/articles/2006/05/18/2809176.htm

7. Anicius Manlius Severinus Boethius. The Fundamentals of Music. Translated by Calvin Bower. Edited by Claude Palisca. New Haven: Yale University Press, 1989.

(C) 2015 by the author; licensee MDPI, Basel, Switzerland. This article is an open access article distributed under the terms and conditions of the Creative Commons Attribution license (http://creativecommons.org/licenses/by/4.0/). 